\title{
PENGARUH BOOK TAX DIFFERENCES DAN ARUS KAS TERHADAP PERSISTENSI LABA \\ (Studi Empiris pada Perusahaan Manufaktur yang Terdaftar di BEI)
}

\author{
Dian Ariyani \\ Rosita Wulandari \\ Universitas Pamulang \\ rosita_1882@yahoo.co.id
}

\begin{abstract}
This study aims to determine the effect of book tax differences and cash flow on earnings persistence. The population in this study is a manufacturing company listed on the Indonesia Stock Exchange 2010-2015. Sampling technique in this research is done by purposive sampling method. Pursuant to purposive sampling method, sample obtained counted 24 company. The type of this research is associative research using quantitative method. The analytical method used to test the influence of book tax differences and cash flow to earnings persistence is multiple regression method with the help of software SPSS version 22. The results showed that partially, permanent differences significantly negatively affect earnings persistence, temporary differences negatively significant effect on persistence Profit, and cash flow have a significant positive effect on earnings persistence. The results of the study simultaneously show that if the permanent differences, temporary differences and cash flows have a significant effect on earnings persistence.
\end{abstract}

Keywords: Permanent Differences, Temporary Differences, Cash Flow, Earnings Persistence

\section{PENDAHULUAN}

Proses akhir di dalam suatu siklus akuntansi yaitu didapatkannya hasil berupa laporan keuangan. Salah satu bagian dari laporan keuangan yang mendapatkan banyak perhatian dari pihak internal maupun eksternal perusahaan adalah informasi mengenai laba. Laba sering digunakan sebagai dasar pertimbangan dalam pengambilan keputusan oleh para pengguna laporan keuangan, sehingga diharapkan laba yang dilaporkan adalah laba yang berkualitas yaitu laba akuntansi yang memiliki sedikit atau tidak mengandung gangguan persepsian (perceived noise) dan mencerminkan kinerja perusahaan yang sesungguhnya (chandarin dalam Zdulhiyanov, 2015:4).

Laba dalam laporan keuangan juga sering digunakan oleh manajemen untuk menarik calon investor dan kreditor sehingga tidak jarang laba tersebut sering direkayasa sedemikian rupa oleh manajemen. Sering kali para investor hanya 
terfokus pada tingkat laba suatu perusahaan tanpa mengetahui dengan pasti apakah informasi yang terkandung dalam laba tersebut mempunyai kualitas tinggi atau tidak. Salah satu komponen dari kualitas laba adalah persistensi laba. Sloan (1996) dalam Ridwan (2015:18) menyatakan bahwa "persistensi laba merupakan suatu ukuran yang menjelaskan kemampuan perusahaan untuk mempertahankan jumlah laba yang diperoleh saat ini sampai satu periode masa depan."

Diakhir periode, manajemen menghitung laba perusahaan untuk dua tujuan setiap tahunnya, yaitu tujuan untuk pelaporan keuangan dan pelaporan pajak. Dalam penyusunan laporan keuangan perusahaan sering kali terjadi perbedaan antara laba akuntansi dengan laba fiskal. Resmi (2011:369) menjelaskan jika laporan keuangan komersial atau bisnis ditujukan untuk menilai kinerja ekonomi dan keadaan finansial dari sektor swasta, sedangkan laporan keuangan fiskal lebih ditujukan untuk menghitung pajak. Untuk kepentingan komersial atau bisnis, laporan keuangan disusun berdasarkan prinsip yang berlaku umum, yaitu Standar Akuntansi Keuangan (SAK), sedangkan untuk kepentingan fiskal, laporan keuangan disusun berdasarkan peraturan perpajakan (Undang-undang Pajak Penghasilan atau disingkat UU PPh). Perbedaan dasar penyusunan laporan keuangan tersebut mengakibatkan perbedaan penghitungan laba (rugi) suatu entitas (Wajib Pajak).

Perbedaan antara laba akuntansi dengan laba fiskal dikenal dengan istilah book tax differences. Book tax differences terbentuk karena disebabkan oleh perbedaan permanen dan perbedaan temporer. Book tax differences yang terjadi setiap tahunnya akan berdampak pada pertumbuhan laba suatu periode perusahaan dikarenakan perusahaan harus menyesuaikan kembali perhitungan laba akuntansinya dengan aturan perpajakan dan hal ini dapat menimbulkan peluang terjadinya manajemen laba yang mengindikasikan bahwa perusahaan mempunyai kualitas laba yang buruk dan kurang persisten.

Faktor lain yang diprediksi dapat mempengaruhi persistensi laba adalah arus kas. Data arus kas merupakan indikator keuangan yang baik, hal ini dikarenakan arus kas relatif lebih sulit untuk dimanipulasi. Arus kas dapat menunjukkan efektif atau tidaknya suatu perusahaan dalam mengelola dana yang dimilikinya. Kondisi 
arus kas yang bernilai positif cenderung akan lebih memberikan kepercayaan terhadap kemampuan perusahaan memperoleh laba di masa depan.

Penelitian tentang persistensi laba yang menggunakan book tax differences sebagai fokus penelitiannya menunjukkan hasil yang masih belum konsisten satu sama lain. Disisi lain, penelitian mengenai pengaruh arus kas terhadap persistensi laba seperti yang telah dilakukan oleh Asma (2013), Barus dan Rica (2014) serta Dewi dan Putri (2015) menunjukkan jika aliran kas operasi berpengaruh positif terhadap persistensi laba.

\section{TELAAH LITERATUR DAN PENGEMBANGAN HIPOTESIS}

\section{Teori Keagenan (Agency Theory)}

Menurut Anthony dan Govindarajan (2009) dalam Wikawati (2014:5) teori agensi adalah hubungan atau kontrak antara principal dan agent. Teori keagenan (agency theory) menjelaskan bahwa hubungan agensi muncul ketika satu orang atau lebih (principal) mempekerjakan orang lain (agent) untuk memberikan suatu jasa dan kemudian mendelegasikan wewenang pengambilan keputusan kepada agen tersebut (Jensen and Meckling, 1976 dalam Ridwan, 2015:13).

Hubungan antara principal dan agen dapat mengarah pada kondisi ketidakseimbangan informasi (asymmetrical information) karena agen berada pada posisi yang memiliki informasi yang lebih banyak tentang perusahaan dibandingkan dengan principal. Dalam kondisi yang asimetri tersebut, agen dapat mempengaruhi angka-angka akuntansi yang disajikan dalam laporan keuangan dengan cara melakukan manajemen laba (Sahara, 2016:12). Apabila angka laba yang dilaporkan dapat diduga oleh publik sebagai hasil dari perekayasaan, maka angka laba tersebut dapat dinilai mempunyai kualitas laba yang rendah dan disebut kurang persisten (Hanlon, 2005 dalam Dewi, 2015:5).

\section{Perbedaan Laba Akuntansi dengan Laba fiskal (Book Tax Differences)}

Book tax differences merupakan perbedaan jumlah laba yang dihitung berdasarkan akuntansi dengan laba yang dihitung sesuai dengan peraturan perpajakan. Terbentuknya book tax differences tersebut disebabkan adanya perbedaan permanen dan perbedaan temporer. 


\section{Perbedaan permanen}

Perbedaan tetap/permanen (permanent differences) adalah perbedaan yang terjadi karena peraturan perpajakan menghitung laba fiskal berbeda dengan perhitungan laba menurut SAK tanpa ada koreksi dikemudian hari (Suandy, 2011:87).

\section{Perbedaan temporer}

Perbedaan temporer dimaksudkan sebagai perbedaan antara dasar pengenaan pajak (tax base) dari suatu aset atau kewajiban dengan nilai tercatat pada aset atau kewajiban yang berakibat pada perubahan laba fiskal periode mendatang. Terjadinya perubahan tersebut dapat bertambah (future taxable amount) atau berkurang (future deductible amount) pada saat aset dipulihkan atau kewajiban dilunasi/dibayar (Waluyo, 2012:271)

\section{Arus Kas}

Menurut Sugiarto (2010:1.32) kas adalah arus masuk atau arus keluar dari kas (uang dan rekening giro) atau setara kas (investasi jangka pendek yang berisiko kecil). Penerimaan kas dan pembayaran kas selama suatu periode diklasifikasikan dalam laporan arus kas menjadi tiga aktivitas berbeda, yaitu aktivitas operasi, investasi, dan pembiayaan/pendanaan.

\section{Persistensi Laba}

Persistensi laba merupakan suatu ukuran yang menjelaskan kemampuan perusahaan untuk mempertahankan jumlah laba yang diperoleh saat ini sampai satu periode masa depan (Sloan (1996) dalam Ridwan (2015). Adapun menurut Penman (1992) dalam Wijayanti (2006:10) persistensi laba adalah revisi dalam laba akuntansi yang diharapkan dimasa mendatang (expected future earnings) yang diimplikasi oleh inovasi laba tahun berjalan (current earnings).

Persistensi laba mengindikasikan laba yang berkualitas karena menunjukkan bahwa perusahaan dapat mempertahankan laba dari waktu ke waktu, serta menggambarkan perusahaan tidak melakukan suatu tindakan yang dapat 
menyesatkan pengguna informasi, karena laba perusahaan yang tidak berfluktuatif tajam (Zdulhiyanov, 2015:5).

\section{Pengembangan Hipotesis:}

Untuk mengetahui adanya pengaruh book tax differences dan arus kas terhadap persistensi laba, maka diperlukan pengujian hipotesis dengan menggunakan uji statistik sebagai berikut:

Penelitian yang dilakukan Ridwan (2015) mengenai analisis book tax differences terhadap persistensi laba menunjukkan hasil jika perbedaan permanen berpengaruh secara signifikan dengan arah positif terhadap persistensi laba. Dewi dan Putri (2015) serta Pratiwi dan Zulaikha (2014) juga menemukan hal serupa jika perbedaan permanen berpengaruh positif terhadap persistensi laba. Adapun penelitian yang dilakukan oleh Ajrina (2015) menunjukkan jika perbedaan tetap secara negatif berhubungan signifikan terhadap persistensi laba. Berdasarkan penelitian tersebut maka dirumuskan hipotesis sebagai berikut:

\section{H1a : Perbedaan permanen berpengaruh positif terhadap persistensi laba}

Penelitian yang dilakukan oleh Pratiwi dan Zulaikha (2014) mengenai analisis pengaruh book tax differences terhadap persistensi laba menunjukkan hasil jika perbedaan temporer memiliki pengaruh negatif terhadap persistensi laba. Hasil yang serupa juga didapatkan oleh Ary Ridwan (2015) dan Ajrina (2015) yang menunjukkan jika perbedaan temporer berpengaruh secara signifikan dengan arah negatif terhadap persistensi laba. Dilain pihak, Dewi dan Putri (2015) menemukan jika perbedaan temporer berpengaruh positif terhadap persistensi laba. Berdasarkan penelitian tersebut maka dirumuskan hipotesis sebagai berikut:

\section{H1b : Perbedaan temporer berpengaruh negatif terhadap persistensi laba}

Arus kas merupakan aliran kas masuk dan aliran keluar serta sumber dan pemakaian kas dalam suatu perusahaan pada periode tertentu. Asma (2013) menemukan jika aliran kas operasi berpengaruh signifikan positif terhadap peresistensi laba. Barus dan Rica (2014) serta Dewi dan Putri (2015) juga menemukan jika aliran kas operasi berpengaruh positif signifikan terhadap persistensi laba. Berdasarkan penelitian tersebut maka dirumuskan sebagai berikut: 


\section{$\mathrm{H}_{2}$ : Arus kas berpengaruh positif terhadap persistensi laba}

Penelitian yang dilakukan Asma (2013) mengenai pengaruh aliran kas dan perbedaan antara laba akuntansi dengan laba fiskal terhadap persistensi laba menunjukkan jika arus kas operasi dan perbedaan antara laba akuntansi dengan laba fiskal secara serentak terdapat pengaruh yang signifikan. Berdasarkan penelitian tersebut dirumuskan sebagai berikut:

\section{$\mathrm{H}_{3}$ : Perbedaan permanen, perbedaan temporer, dan arus kas berpengaruh terhadap persistensi laba}

\section{METODE PENELITIAN DAN PEMBAHASAN}

Jenis data dalam penelitian ini adalah data sekunder berupa laporan keuangan perusahaan manufaktur yang terdaftar di Bursa Efek Indonesia untuk periode tahun 2010-2015. Sumber data laporan keuangan perusahaan yang telah diaudit tahun 20102015 diperoleh dari www.idx.co.id.

Populasi dalam penelitian ini adalah seluruh perusahaan manufaktur yang sudah go public yang terdaftar di Bursa Efek Indonesia selama periode 2010-2015. Adapun sampel dalam penelitian ini adalah sebanyak 120 yang terdiri dari 24 perusahaan manufaktur yang terdaftar di BEI tahun 2010-2015. Pemilihan sampel pada penelitian ini menggunakan teknik purposive sampling, yaitu teknik penentuan sampel dengan pertimbangan tertentu (Sugiyono, 2009:85). Kriteria perusahaan yang digunakan untuk pemilihan sampel adalah sebagai berikut:

1. Perusahaan manufaktur yang terdaftar berturut-turut di BEI tahun 2010-2015 dan tidak di delisting selama periode pengamatan penelitian.

2. Mempublikasikan laporan keuangan auditan per 31 Desember secara konsisten selama tahun 2010-2015.

3. Laporan keuangan dinyatakan dalam mata uang rupiah.

4. Perusahaan tidak mengalami kerugian dalam laporan keuangan umum dan laporan keuangan pajak selama tahun 2010-2015.

5. Perusahaan tidak memiliki arus kas operasi yang negatif selama tahun 2010-2015. 
6. Memiliki kelengkapan informasi yang dibutuhkan terkait dengan indikator perhitungan yang dijadikan variabel pada penelitian.

Variabel merupakan segala sesuatu yang akan menjadi objek pengamatan dalam penelitian yang merupakan suatu konsep yang memiliki variasi nilai.

a. Variabel bebas/independent variable (variabel X)

1) Perbedaan permanen $\left(X_{1 a}\right)$

Perbedaan permanen diperoleh dari perbedaan permanen baik positif maupun negatif. Besarnya perbedaan permanen diketahui dari catatan atas laporan keuangan dan dibagi dengan total aset (Dewi dan Putri, 2015:251).

\section{Jumlah Perbedaan Permanen}

\section{Total Aset}

2) Perbedaan temporer $\left(X_{1 b}\right)$

Perbedaan temporer diperoleh dari perbedaan temporer baik positif maupun negatif. Besarnya perbedaan temporer diketahui dari catatan atas laporan keuangan dan dibagi dengan total aset (Dewi dan Putri, 2015:251).

\section{Jumlah Perbedaan Temporer \\ Total Aset}

3) Arus $\operatorname{Kas}\left(\mathrm{X}_{2}\right)$

Arus kas yang digunakan dalam penelitian ini dihitung berdasarkan arus kas operasi (Operating Cash Flow) pada tahun berjalan dibagi dengan total aset (Windarti, 2015:10).

\section{Arus Kas Operasi}

\section{Total Aset}

b. Variabel terikat/dependent variable (variabel Y)

Persistensi Laba (Y)

Pengukuran persistensi laba dapat ditunjukkan dari laba sebelum pajak tahun depan (Pre Tax Book Income / $\mathrm{PTBI}_{\mathrm{t}+1}$ ). Laba sebelum pajak tahun depan $\left(\mathrm{PTBI}_{\mathrm{t}+1}\right)$ merupakan selisih antara pendapatan dan beban pada tahun depan sebelum dikurangi dengan beban pajak. Pengukuran persistensi laba mengacu 
pada penelitian sebelumnya yang dilakukan oleh Dewi dan Putri (2015:250) dengan rumus sebagai berikut:

\section{Laba Sebelum Pajak $\mathrm{t}_{\mathrm{t}-1}$}

\section{Hasil}

\section{Uji Asumsi Klasik}

1. Uji Normalitas

Hasil pengujian normalitas menggunakan kolmogrov tampak pada tabel 1 dibawah ini :

Tabel 1

Hasil Uji One Sample K-S

One-Sample Kolmogorov-Smirnov Test

\begin{tabular}{|ll|r|}
\hline & & \multicolumn{2}{|c|}{ Unstandardized Residual } \\
\hline N & & 120 \\
Pormal & Mean &, 0000000 \\
Most Extreme & Absolute &, 07480620 \\
Differences & Positive &, 081 \\
& Negative &, 081 \\
Test Statistic & &,- 065 \\
Asymp. Sig. (2-tailed) &, 081 \\
\hline
\end{tabular}

a. Test distribution is Normal.

b. Calculated from data.

c. Lilliefors Significance Correction.

Sumber : Data hasil output SPSS versi 22

Dari hasil uji kolmogrov smirnov menunjukkan nilai asymp.sig.(2-tield) sebesar 0,052 yang berarti nilainya lebih besar dari 0,05 maka dapat disimpulkan bahwa data residual pada model regresi terdistribusi secara normal. 
2. Uji Multikolonieritas

Tabel 2.

Hasil Uji Multikolonieritas

Coefficients ${ }^{\mathrm{a}}$

\begin{tabular}{|c|c|c|}
\hline \multirow[b]{2}{*}{ Model } & \multicolumn{2}{|c|}{ Collinearity Statistics } \\
\hline & Tolerance & VIF \\
\hline 1 (Constant) & & \\
\hline PBTD & 917 & 1,091 \\
\hline TBTD & ,919 & 1,088 \\
\hline OCF & ,953 & 1,049 \\
\hline
\end{tabular}

Dependent Variable: PTBIt+1

Dari tabel 2 dibawah ini dapat dilihat tidak ada variabel independen yang memiliki nilai tolarance kurang dari 0,10 dan tidak ada satupun variabel independen yang memiliki nilai VIF lebih dari 10. Sehingga dapat disimpulkan bahwa tidak terdapat multikoliniearitas antar variabel independen dalam model regresi.

\section{Uji Heteroskedastisitas}

Berikut ini grafik scatterplot hasil uji heteroskedastisitas:

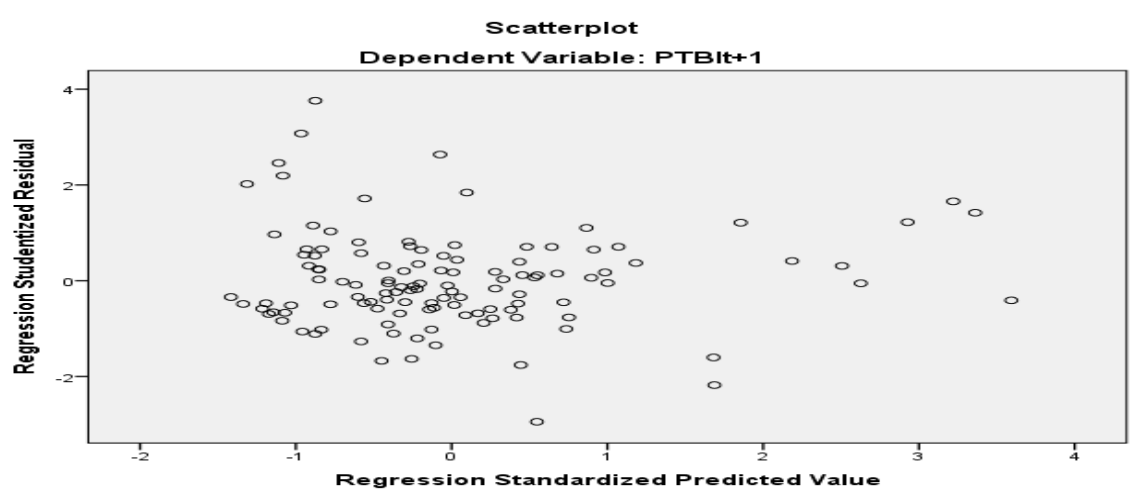

Sumber : Data hasil output SPSS versi 22

Gambar 1

Grafik Scatterplot 
Terlihat jika titik-titik menyebar secara acak baik diatas dan dibawah angka 0 pada sumbu Y dan tidak membentuk suatu pola tertentu yang teratur, sehingga dapat disimpulkan tidak terjadi heteroskedastisitas di dalam model regresi ini.

\section{Uji Autokorelasi}

Tabel 3

\section{Hasil Uji Autokorelasi}

Model Summary ${ }^{b}$

\begin{tabular}{|l|l|r|l|l|l|}
\hline & & \multicolumn{2}{|l|}{$\begin{array}{l}\text { Adjusted } \\
\text { R Square }\end{array}$} & $\begin{array}{c}\text { Std. Error of the } \\
\text { Estimate }\end{array}$ & $\begin{array}{l}\text { Durbin- } \\
\text { Watson }\end{array}$ \\
\hline 1 & $\mathrm{R}$ & R Square & ,612 &, 07576735 & \multicolumn{2}{|c|}{2,079} \\
\hline
\end{tabular}

a. Predictors: (Constant), OCF, TBTD, PBTD

a. Predictors: (Constant), OCF, TBTD, PBTD

b. Dependent Variable: PTBIt+1

Sumber : Data hasil output SPSS versi 22

\section{Analisis Regresi Linier Berganda}

Analisis regresi linier berganda dalam penelitian ini digunakan untuk menguji pengaruh variabel independen terhadap variabel dependen. Hasil pengujian regresi linier berganda dapat dilihat pada tabel 5 berikut ini:

\section{Tabel 4}

Coefficients $^{\mathrm{a}}$

\begin{tabular}{|c|c|c|c|c|c|}
\hline \multirow[b]{2}{*}{ Model } & \multicolumn{2}{|c|}{ nstandardized Coefficien } & \multirow{2}{*}{$\begin{array}{c}\begin{array}{c}\text { Standardized } \\
\text { Coefficients }\end{array} \\
\text { Beta }\end{array}$} & \multirow[b]{2}{*}{$\mathrm{t}$} & \multirow[b]{2}{*}{ Sig. } \\
\hline & B & Std. Error & & & \\
\hline (Constant) & ,048 & ,013 & & 3,599 & 000 \\
\hline PBTD &,- 562 & ,281 &,- 119 & $-1,999$ & ,048 \\
\hline TBTD & $-1,447$ & 687 &,- 125 & $-2,108$ & ,037 \\
\hline $\mathrm{OCF}$ & 887 & ,070 & ,742 & 12,696 &, 000 \\
\hline
\end{tabular}

a. Dependent Variable: PTBIt+1

Sumber : Data hasil output SPSS versi 22 
Dari tabel 4 diatas maka dapat dilihat persamaan regresi yang digunakan dalam penelitian ini adalah:

PTBI $_{t+1}=0,048-0,562$ PBTD $-1,447$ TBTD $+0,887$ OCF

Konstanta sebesar 0,048, artinya jika perbedaan permanen (PBTD), perbedaan temporer (TBTD), dan arus kas (OCF) nilainya adalah 0, maka persistensi laba nilainya sebesar 0,048 .

Pada koefisien regresi variabel perbedaan permanen (PBTD) menunjukkan tanda negatif, hal ini berarti variabel permanen memiliki pengaruh negatif terhadap persistensi laba. Koefisien regresi perbedaan permanen sebesar -0,562, artinya setiap perbedaan permanen mengalami kenaikan sebesar 1 maka persistensi laba akan mengalami penurunan sebesar 0,562 .

Pada koefisien regresi variabel perbedaan temporer (TBTD) menunjukkan tanda negatif, hal ini berarti variabel temporer memiliki pengaruh negatif terhadap persistensi laba. Koefisien regresi perbedaan temporer sebesar $-1,447$, artinya setiap perbedaan temporer mengalami kenaikan sebesar 1 maka persistensi laba akan mengalami penurunan sebesar 1,447 .

Pada koefisien regresi variabel arus kas (OCF) menunjukkan tanda positif, hal ini berarti variabel arus kas memiliki pengaruh positif terhadap persistensi laba. Koefisien regresi arus kas sebesar 0,887, artinya setiap arus kas mengalami kenaikan sebesar 1 maka persistensi laba akan mengalami peningkatan sebesar 0,887.

\section{Uji Statistik t}

\section{Tabel 5}

\section{Hasil Uji Statistik t}

Coefficients $^{\mathrm{a}}$

\begin{tabular}{|c|c|c|c|c|c|}
\hline \multirow[b]{2}{*}{ Model } & \multicolumn{2}{|c|}{$\begin{array}{l}\text { Unstandardized } \\
\text { Coefficients }\end{array}$} & \multirow{2}{*}{$\begin{array}{c}\text { Standardized } \\
\text { Coefficients }\end{array}$} & \multirow[b]{2}{*}{$\mathrm{t}$} & \multirow[b]{2}{*}{ Sig. } \\
\hline & B & Std. Error & & & \\
\hline (Constant) & ,048 & ,013 & & 3,599 & ,000 \\
\hline PBTD &,- 562 & ,281 &,- 119 & 1,999 & ,048 \\
\hline
\end{tabular}




\begin{tabular}{|l|r|r|r|r|l|} 
TBTD & - &, 687 &,- 125 & 2,108 &, 037 \\
& 1,447 & & & & \\
OCF &, 887 &, 070 &, 742 & 2,696 &, 000 \\
\hline
\end{tabular}

a. Dependent Variable: PTBIt+1

Sumber : Data hasil output SPSS versi 22

Varibel perbedaan permanen (PBTD) memiliki nilai $t_{\text {hitung }}$ sebesar $-1,999$ dengan nilai signifikansi sebesar 0,048. Hal ini menunjukkan $t_{\text {hitung }}>t_{\text {tabel }}(1,999>$ 1,65810) dan nilai signifikansi lebih kecil dari $0,05(0,048<0,05)$, ini berarti perbedaan permanen berpengaruh negatif signifikan terhadap persistensi laba. Dengan demikian maka $\mathrm{H}_{1 a}$ yang menyatakan perbedaan permanen berpengaruh positif terhadap persistensi laba, ditolak.

Varibel perbedaan temporer (TBTD) memiliki nilai thitung sebesar -2,108 dengan nilai signifikansi sebesar 0,037. Hal ini menunjukkan thitung $>t_{\text {tabel }}(2,108>$ 1,65810) dan nilai signifikansi lebih kecil dari $0,05(0,037<0,05)$. Dengan demikian maka $\mathrm{H}_{1 \mathrm{~b}}$ yang menyatakan perbedaan temporer berpengaruh negatif terhadap persistensi laba, diterima.

Varibel arus kas (OCF) memiliki nilai thitung sebesar 12,696 dengan nilai signifikansi sebesar 0,000. Hal ini menunjukkan bahwa $t_{\text {hitung }}>t_{\text {tabel }}(12,696>$ $1,65810)$ dan nilai signifikansi lebih kecil dari $0,05(0,000<0,05)$. Dengan demikian maka $\mathrm{H}_{2}$ yang menyatakan arus kas berpengaruh positif terhadap persistensi laba, diterima.

\section{Uji Statistik F}

\section{Tabel 6}

\section{Hasil Uji Statistik F}

ANOVA $^{\mathrm{a}}$

\begin{tabular}{|l|r|r|r|r|c|}
\hline \multicolumn{1}{|c|}{ Model } & Sum of Squares & df & Mean Square & F & Sig. \\
\hline 1 Regression & 1,097 & 3 &, 366 & 63,681 &, $000^{\mathrm{b}}$ \\
Residual &, 666 & 116 &, 006 & & \\
Total & 1,763 & 119 & & & \\
\hline
\end{tabular}

a. Dependent Variable: PTBIt+1

b. Predictors: (Constant), OCF, TBTD, PBTD 
Dari hasil uji statistik f pada tabel 4 menunjukkan nilai $F_{\text {hitung }}$ sebesar 63,681 dengan nilai signifikansi sebesar 0,000. Sedangkan pada $F_{\text {tabel }}$ dengan tingkat signifikansi $0,05(\alpha=5 \%)$ diperoleh angka sebesar 2,68. Karena $F_{\text {hitung }}>F_{\text {tabel }}$ $(63,681>2,68)$ dan nilai signifikansi lebih kecil dari $0,05(0,000<0,05)$, dengan demikian maka dapat disimpulkan bahwa model regresi dalam penelitian ini valid dan dapat digunakan.

\section{Koefisien Korelasi $(\mathbf{R})$ dan Determinasi $\left(\mathbf{R}^{2}\right)$}

Tabel 7

Hasil Uji Koefisien Korelasi Berganda $(\mathbf{R})$ dan Determinasi $\left(\mathbf{R}^{\mathbf{2}}\right)$

Model Summary

\begin{tabular}{|l|r|r|r|r|}
\hline Model & $\mathrm{R}$ & R Square & \multicolumn{1}{c|}{$\begin{array}{c}\text { Adjusted R } \\
\text { Square }\end{array}$} & Std. Error of the Estimate \\
\hline 1 &, $789^{\mathrm{a}}$ &, 622 &, 612 &, 07576735 \\
\hline
\end{tabular}

a. Predictors: (Constant), OCF, TBTD, PBTD

Sumber : Data hasil output SPSS versi 22

Berdasarkan hasil uji koefisien korelasi berganda pada tabel 6 diatas, diperoleh angka $\mathrm{R}$ sebesar 0,789 . Nilai 0,789 tersebut berada pada rentang 0,60 0,799, itu artinya antara perbedaan permanen, perbedaan temporer, dan arus kas terhadap persistensi laba memiliki hubungan yang kuat.

Adapun nilai adjusted $R$ square adalah sebesar 0,612 , hal ini menunjukkan bahwa sebesar $61,2 \%$ hubungan variabel dependen yaitu persistensi laba dapat dijelaskan oleh variabel-variabel independen yaitu perbedaan permanen, perbedaan temporer, dan arus kas. Sedangkan sisanya sebesar 38,8\% dijelaskan oleh faktorfaktor lain yang tidak dimasukkan dalam model regresi pada penelitian ini. 


\section{Pembahasan}

\section{Pengaruh perbedaan permanen terhadap persistensi laba}

Berdasarkan hasil pengujian statistik $\mathrm{t}$ pada tabel 5 menunjukkan jika variabel perbedaan permanen berpengaruh negatif signifikan terhadap persistensi laba. Hal tersebut menunjukkan bahwa perbedaan permanen didominasi oleh pospos yang akan ditambahkan kembali ke dalam rekonsiliasi fiskal yaitu beban yang tidak dapat dikurangkan atau kerugian anak perusahaan dan bersifat non recurring item (tidak berulang). Akibat dari komponen perbedaan permanen lebih banyak mencakup beban yang tidak diperkenankan maka akan berdampak pada book tax differences negatif (laba akuntansi lebih kecil dari pada laba pajak) dan menyebabkan persistensi laba menjadi rendah karena pajak yang dibayarkan semakin tinggi.

Hasil penelitian ini konsisten dengan penelitian yang dilakukan oleh Ajrina (2015) yang membuktikan bahwa perbedaan permanen secara negatif saling berhubungan signifikan terhadap persistensi laba.

\section{Pengaruh perbedaan temporer terhadap persistensi laba}

Berdasarkan hasil pengujian statistic $\mathrm{t}$ pada tabel 5 menunjukkan jika variabel perbedaan temporer berpengaruh negatif signifikan terhadap persistensi laba. Perbedaan temporer mengakibatkan pergeseran pengakuan penghasilan dan biaya antara satu tahun pajak ke tahun pajak lainnya, sehingga mengakibatkan besarnya laba fiskal menjadi lebih tinggi dari pada laba akuntansi atau sebaliknya. Perbedaan temporer merupakan komponen laba transitori sehingga menurunkan persistensi laba. Perusahaan yang memiliki perbedaan temporer cenderung memiliki laba yang tidak persisten. Kondisi ini terjadi akibat dari pembalikan atas dasar perbedaan temporer di masa yang akan datang sehingga perbedaan waktu memikiki hubungan negatif terhadap persistensi laba.

Hasil penelitian ini konsisten dengan penelitian yang dilakukan oleh Ridwan (2015) dan Ajrina (2015) yang membuktikan bahwa perbedaan temporer secara negatif saling berhubungan signifikan terhadap persistensi laba. Hasil penelitian ini juga mendukung penelitian Pratiwi dan Zulaikha (2014) yang menemukan bahwa perbedaan temporer memiliki hubungan negatif terhadap persistensi laba. 


\section{Pengaruh arus kas terhadap persistensi laba}

Berdasarkan hasil pengujian statistik $\mathrm{t}$ pada tabel 5 menunjukkan jika variabel arus kas berpengaruh positif signifikan terhadap persistensi laba. Semakin besar arus kas operasi periode sekarang maka laba akuntansi sebelum pajak satu periode mendatang akan cenderung meningkat, begitu juga sebaliknya, sehingga dengan semakin besarnya arus kas operasi, persistensi laba dimasa mendatangpun akan dapat terjaga dengan baik. Hasil penelitian ini konsisten dengan penelitian yang dilakukan oleh Asma (2013), Barus dan Rica (2014) serta penelitian yang dilakukan oleh Dewi dan Putri (2015) yang membuktikan arus kas operasi berpengaruh signifikan positif terhadap persistensi laba.

\section{Pengaruh perbedaan permanen, perbedaan temporer, dan arus kas terhadap persistensi laba}

Berdasarkan hasil pengujian statistik f pada tabel 6 menunjukkan jika perbedaan permanen, perbedaan temporer dan arus kas secara simultan berpengaruh signifikan terhadap persistensi laba. Hasil penelitian ini konsisten dengan penelitian yang dilakukan oleh Asma (2013) mengenai pengaruh aliran kas dan perbedaan antara laba akuntansi dengan laba fiskal terhadap persistensi laba yang memberikan hasil jika perbedaan antara laba akuntansi dengan laba fiskal (book tax differences) dan arus kas operasi secara serentak terdapat pengaruh yang signifikan.

\section{SIMPULAN}

1. Perbedaan permanen berpengaruh signifikan dengan arah negatif terhadap persistensi laba.

2. Perbedaan temporer berpengaruh signifikan dengan arah negatif terhadap persistensi laba.

3. Arus kas berpengaruh signifikan dengan arah positif terhadap persistensi laba.

4. Perbedaan permanen, perbedaan temporer, dan arus kas secara simultan berpengaruh signifikan terhadap persistensi laba. 


\section{DAFTAR PUSTAKA}

Agoes, Sukrisno \& Estralita Trisnawati,(2013) “Akuntansi Pepajakan”, Edisi 3, Salemba Empat, Jakarta.

Ajrina, Sheila, (2015) "Hubungan Antara Perbedaan Permanen dan Perbedaan Waktu dengan Persistensi Laba, Universitas Negeri Jakarta.

Asma, Tuti Nur. (2013). "Pengaruh Aliran Kas dan Perbedaan Antara Laba Akuntansi dengan Laba Fiskal Terhadap Persistensi Laba”, Universitas Negeri Padang.

Barus, Adreani Caroline \& Vera Rica, (2014) “Analisis Faktor-Faktor yang Mempengaruhi Persistensi Laba pada Perusahaan Manufaktur di Bursa Efek Indonesia", Jurnal Wira Ekonomi Mikroskil, Volume 4, Nomor 02.

Dewi, Citra Ayu Kusuma, (2015) "Pengaruh Book Tax Differences dan Tingkat Hutang Terhadap Persistensi Laba", Universitas Muhammadiyah Surakarta.

Dewi, Ni Putu Lestari \& I.G.A.M. Asri Dwija Putri, (215) "Pengaruh Book-Tax Difference, Arus Kas Operasi, Arus Kas Akrual, dan Ukuran Perusahaan Pada Persistensi Laba”, E-Jurnal Akuntansi Universitas Udayana 10.1 : 244- 260 ISSN: 2302-8556.

Hadiarrohman, (2011) "Pengaruh Laba Tahun Berjalan, Akrual, dan Arus Kas Terhadap Persistensi Laba dengan Perbedaan Laba Akuntansi dan Laba Fiskal sebagai Variabel Moderating”, UIN Syarif Hidayatullah Jakarta.

Harahap, Sofyan Syafri, (2012) “Teori Akuntansi”, Edisi Revisi 2011, Rajawali Pers, Jakarta.

Harrisson Jr, Walter T., dkk, (2012) “Akuntansi Keuangan: International Financial Reporting Standards-IFRS”, Edisi Kedelapan Jilid 1, Erlangga, Jakarta.

IAI, (2009) “ Standar Akuntansi Keuangan”, Salemba Empat, Jakarta.

Kieso, Donald E., (20018) Jerry J. Weygandt \& Terry D. Warfield, “Akuntansi Intermediet”, Edisi Keduabelas Jilid 1, Erlangga, Jakarta. 
Maulana, Septian, (2016) "Analisis Hubungan Permanent Differences dan Temporary Differences Terhadap Persistensi Laba”, Universitas Pamulang.

Muljono, Djoko \& Baruni Wicaksono, “Akuntansi Pajak Lanjutan”, Andi, Yogyakarta, 2009.

Nuraini, Mety, (2014) “ Analisis Faktor-Faktor Penentu Persistensi Laba”, Universitas Diponegoro.

Persada, Aulia Eka \& Dwi Martani, (2010) "Analisis Faktor yang Mempengaruhi Book Tax Gap dan Pengaruhnya Terhadap Persistensi Laba”, Jurnal Akuntansi dan Keuangan Indonesia, Volume 7 - No.2, hal 205 - 22.

Pratiwi, Intan Ratna \& Zulaikha, (2014) “Analisis Pengaruh Book-Tax Differences Terhadap Persistensi Laba”, Diponegoro Journal of Accounting, Volume 3, Nomor 3 halaman 1-9, ISSN (Online): 2337-3806.

Ridwan, Ary. (2015) “Analisis Book Tax Differences Terhadap Persisitensi Laba”, Universitas Islam Negeri Maulana Malik Ibrahim.

Zdulhiyanov, Mohd, (2015) "Pengaruh Book Tax Differences Terhadap Persistensi Laba”, Universitas Negeri Padang. 